\title{
The Impact of Personality Types on Students' Writing Ability
}

\author{
Hermi Zaswita*, Rodiyal Ihsan \\ Program Studi Pendidikan Bahasa Inggris, STKIP Muhammadiyah Sungai Penuh, Indonesia \\ e-mail: zaswitahermi@gmail.com, rodiyal902@gmail.com
}

\begin{abstract}
Personality is considered one of the internal factors that have an impact on students' ability in language learning. The present study investigated the impact of personality types on their ability in writing English. There are two types of personalities studied: Extrovert and Introvert. The research is quasi-experiment. Students at grade XI Vocational School 1 Sungai Penuh engage in the study, whereas only two classes selected as samples (experimental class and control class). Students were given a personality questionnaire to recognize their personality types. Then, the writing test carries out in each class in order to know the student's ability in writing. The data are analyzed by using t-test. The finding of hypotheses testing proves that the $p$-score is 0,00. Thus, the $p$-score is lower than 0,05 $(0,00<0,05)$ which means $\mathrm{HO}$ is rejected and $\mathrm{H} 1$ is accepted. Hence, there is a significant impact on students' personalities to their writing ability. Students with introvert personalities have better writing scores than students with extrovert personality.
\end{abstract}

Keywords: Personality; Extrovert and Introvert; Vocational School Students; Writing Ability

\section{Introduction}

Writing as one of the skills in English must be learned by language learners, besides listening, speaking, and reading. In the EFL classroom, the students not only wish to learn writing as essential components of learning but also to apply to their academic and professional life. Based on the Indonesian curriculum for Vocational High School, students are targeted to attain the intermediate level in communicating verbally and in writing to interrelate in the context of daily life, the occupation world, and the business world. However, writing in English is not easy for the student, it entails a lot of practice, good vocabulary, and high-quality grammar. It also requires more focus, cognition, and diligence (Dhanya \& Alamelu, 2019) Students as well for a time find it difficult to convey their ideas into text (Bilal, H, Tariq, Din., Latif, \& Anjum, 2013) and also lack vocabulary and difficulties in grammar and syntax (Fareed, Ashraf, \& Bilal, 2016)

The problem sometimes not only caused by students' external factors but also students' internal factors like personality(Faisal, 2019; Fatimawati, 2015) Personality factors within a person that contribute in some way to the success of language learning (Brown, 2000). Each student has the different type of personality that is not the same between students each other so that it is often as an obstacle because it takes a different learning result as between students (Dewaele, 2005).

Dealing with students' personality, there are two types of personalities studied here: extrovert and introvert because these two types are the most researched personality aspect in L2 studies. Some studies about extrovert and Introvert personality types in writing ability has been conducted by some researchers and showed different results (Boroujeni, Roohani, \& Hasanimanesh, 2015; Mansouri Nejad, Bijami, \& Ahmadi, 2012; Zainuddin, 2016). According to (Suryasubrata, 1995; Zabihi, 2011), extroverts are specifically influenced by the objective world, the world outside themselves. The orientation is intended outside; mind. His feelings and actions are determined by the environment both social and non-social. He always has a positive attitude towards society, cares and, has good relatsions with others. Introverts, on the other hand, are influenced by the subjective world; the world inside him.

\footnotetext{
Corresponding author.

Received 24 September 2019; Accepted 28 March 2020; Available online 31 March 2020 (c) 2020 JPI. All Rights Reserved
} 
The orientation tends to be inside; thoughts, feelings and, actions are determined by subjective factors. Adaptation to the outside world is not very good; difficult to have relationships with other people. (Machnicka, 2010) adds that an extrovert can get along; he does more than just contemplate and has a motive that is coordinated by external activities. An extrovert is easy to adapt to new environments and is usually energized with people and interacts with them, and is able to think well if he is talking about his ideas with others. On the other hand, introverts think for themselves by processing ideas in their own minds.

In language learning, extrovert and introvert students also have their strengths and weaknesses. (Loewen \& Reinders, 2007) states that extroversion can affect second language learning because extroverts are more likely to look for opportunities to interact with other speakers of the second language. Conversely, introverts may have fewer opportunities to interact, because of their personality types. (Pritchard, 2014) recognizes that extrovert students like: talking to understand new information and ideas; work in groups; try something first and think later. Extroverts learn best when they can work with friends and learn by trying something themselves instead of watching or listening to others. When they have difficulty understanding, they can talk about their ideas with others. Meanwhile, introvert students like self-study, listening to other people talk and think about information in private; think about something first and try later; listen, observe, write and read; take time to complete the task. Introverts do well when they can find quiet places to work and have enough time to reflect, reformulate, and improve their work. Introverts often connect schoolwork and their personal interests. (Shahila, Zafar, \& Meenakshi, 2012) proposed that the introvert students' in the class can be also involved in language learning if teachers provide their students with a sense of security and encourage them to voice their opinion. Once the students are not afraid of being blamed and humiliated when they talk, they will take part in the class willingly and do well in second language acquisition.

Furthermore, in speaking ability, the introverts have better pronunciation and good vocabulary than the extroverts. It is found that extroverts are likely to try out a large amount and variety of different word types with high speech rates and legible pronunciation. Meanwhile, when the introvert students are asked to read out loud in the class, they are reading slowly and carefully with good pronunciation but with low speech rates (Shrum, Glisan, \& W, 2010; Suliman, 2014; Wakamoto, 2000). Dealing with grammar mastery, the introverts tend to have better grammar in speaking than the extroverts, since the introverts will speak carefully with soft voices. They also consider grammar when confessing the idea in speaking. This idea is supported by (Laney \& Laney, 1987) which mention that the introverts think before they act or speak, although when speaking they have soft voices, appear calm, pause frequently may sound hesitant, and may hunt for words. Meanwhile, the extroverts act first and think later.

On the contrary, the introverts have better comprehension in reading skills, while the extroverts tend to comprehend in someone's speaking. When someone speaks, extroverts generally can comprehend it well. (Nicholson, 2015) mentions that the introverts have good reading comprehension since they spend a lot of time by reading a book, magazine, newspaper (spending time in the library) or consuming information in a different form. The research findings from (Ahour \& Haradasht, 2014) also state that introverts were generally better readers than extroverts. This is very much understandable if the paradigm of extroversion and introversion is put together in context: extroverts outweigh introverts in the amount of speech but they do not necessarily gain more than introverts when it comes to reading comprehension. Thus, related to comprehension aspect, both extroverts and introverts also have equal ability.

Moreover, in writing ability, particularly some researchers find that there are also differences result between extrovert personality and introvert personality. (Marwa \& Thamrin, 2016) obtained that there was a positive correlation between extroversion personality and students' argumentative essay writing skills. The dominant level of extroversion personality was fairly extrovert and the students who are included in fairly extroverted obtained the argumentative essay score in the acceptable category than introvert one. In the contrary, a study conducted by (Zainuddin, 2016) found that introvert EFL learners did better than 
extrovert EFL learners in constructing sentences (syntax). (Boroujeni et al., 2015) also gained if introverts significantly outperformed extroverts in all subsets of writing components except organization. This may be due to some of the introverts' personal characteristics that the extroverts lack, such as being careful, having more concentration in their solitude, and ability to generate many more ideas.

The present study focused on the impact of personality types (extrovert and introvert) on students' writing ability, especially in writing a business letters, as one of the writing material learned in Vocational School.

\section{Method}

This study is quasi-experimental research. Two classes of grade XI Vocational School 1 Sungai Penuh were chosen as the sample. The chosen two classes aimed to compare and ensure that whether there is a significant impact of personality on students' writing ability or not, XI Accounting 1 as an experimental class, and XI Accounting 2 as a control class. There were 32 students involved in the study. The instrument applied in collecting data in this study were a personality questionnaire that used to get the data about students' personality and writing test in order to get data about students' writing ability. Questionnaire constructed from International Item Pool (IIP) indicators (Mastuti, 2005) which consists of 25 items.

Afterward, the data must be validated to the normality and homogeneity. Normality testing intended to see if the data obtained from research with normal distribution, analyze by using the Anderson Darling test with SPSS. Homogeneity testing strived to perceive whether the data from both samples which have homogeneous variance or not. In homogeneity testing used F-test with SPSS. After the confirmation of normality and homogeneity of the data, the hypothesis testing was conducted. Hypothesis examined by t-test analysis in measuring the significant of the mean difference. The calculation was executed via SPSS. The hypotheses in the study are as follow:

$\mathrm{H} 1$ : There is a significant impact of students' personalities on students' writing ability. $\mathrm{HO}$ : There is no significant impact of students' personalities on students' writing ability.

\section{Result and Discussion}

\subsection{Result}

This study groups students' personalities into two categories, students with extrovert personalities and introvert students. To determine whether students are extrovert and introvert individuals, (Arikunto, 2008) suggests taking $27 \%$ of the top questionnaire scores asextrovert personality students and $27 \%$ of the lowest scores of questionnaires as introvert personality students. For this reason, 4 students from the top scores were taken as students with an extrovert personality and 4 students from the lowest scores were taken as students with an introvert personality. It applies both in the control class and in the experimental class because the number of students is the same in both classes. Description of student personality data can be seen in the following table:

Table 1. Student Personality Data in the Experiment Class and Control Class

\begin{tabular}{ccccccccc}
\hline Class & $\mathbf{N}$ & Mean & Med & Max & Min & Variance & SD & Total \\
\hline Experimental & 16 & 78.5 & 82,5 & 108 & 50 & 344,8 & 18.6 & 1256 \\
Control & 16 & 79.3 & 82 & 110 & 53 & 360.4 & 19 & 1270 \\
\hline
\end{tabular}

It is shown that the minimum personality scores of control class students were 53 and 50 in the experimental class. The maximum scores of students in the control class were 110 and 108 in the experimental class. And the average score in the control class was 79.3 and in the experimental class 78.5. Then to test whether the student personality data from the control class and the experimental class were normally distributed, Anderson Darling's test was performed using SPSS. Provided that if P-value $>0.05$ then $\mathrm{HO}$ is accepted and if $\mathrm{P}$ score $<0.05$ then $\mathrm{HO}$ is rejected. The experimental class is normally distributed because the $\mathrm{P}$-value is 0.205 , so $\mathrm{H} 0$ is accepted. As seen in the following image. 


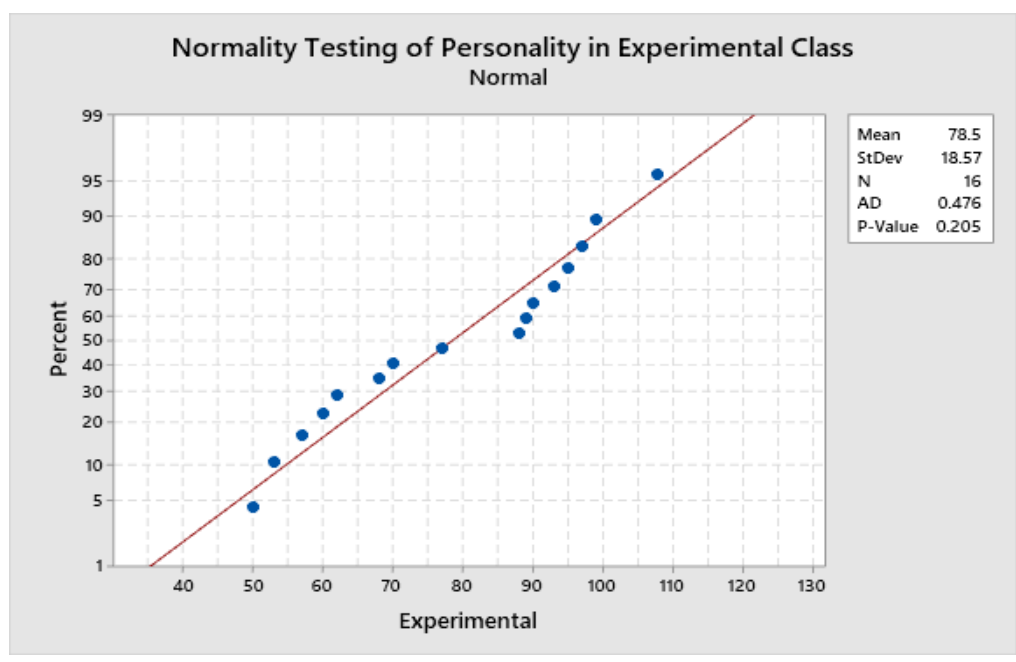

Figure 1. Normality Testing of Personality in Experimental Class

And the personality of students from the control class is also normally distributed because the $\mathrm{P}$-value is 0.251 , so $\mathrm{H} 0$ is accepted. As seen in the following image:

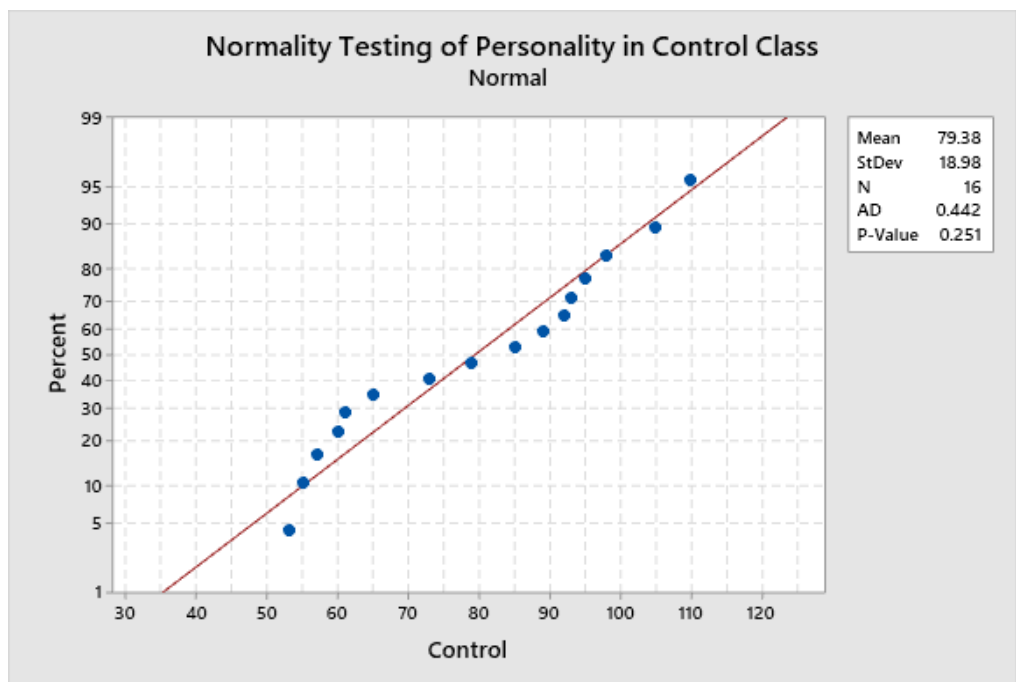

Figure 2. Normality Testing of Personality in Control Class

To find out whether the personality data of students from the control and experimental class is homogeneous, then the homogeneity of the data is tested using the F-Test via SPSS. Homogeneity test serves to find out that two or more groups of data are taken from populations that have the same variance. The homogeneity test provisions are by looking at the P score if $>0.05$ then both groups have the same or homogeneous variance based on the F-Test formula. The results obtained using the F-Test formula of 0.933 so that both class groups are declared homogeneous. Can be seen in the following figure: 


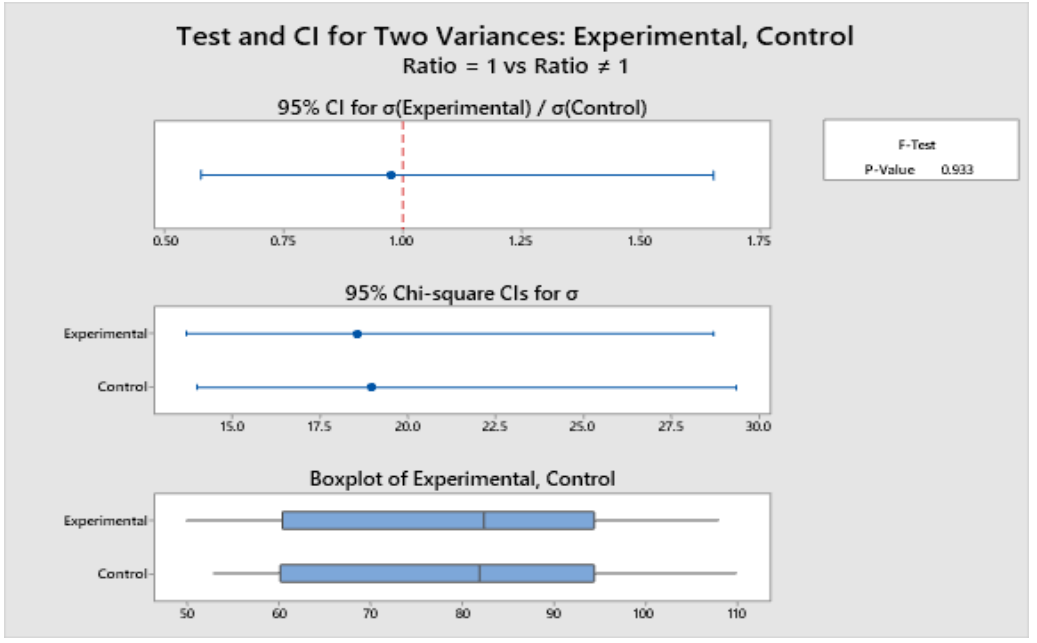

Figure 3. Homogeneity Testing of Student Personality Data in Experimental and Control Class

Furthermore, student personality data is divided into 2 groups, namely groups of students with an extrovert personality and students with an introvert personality. As has been explained at the outset that the 4 highest scoring students and the 4 lowest scoring students were taken to be grouped according to personality. The following is a summary of student personality grouping data:

Table 2. Grouping Students Based on Personality in the Experiment Class and Control Class

\begin{tabular}{ccccccccc}
\hline Class & $\begin{array}{c}\text { Personality } \\
\text { Student }\end{array}$ & $\mathbf{N}$ & Mean & Max & Min & Variance & SD & Total \\
\hline \multirow{2}{*}{ Experimental } & Extrovert & 4 & 99.7 & 108 & 95 & 32.9 & 5.7 & 399 \\
& Introvert & 4 & 55 & 60 & 50 & 19.3 & 4,3 & 220 \\
Control & Extrovert & 4 & 102 & 110 & 95 & 46 & 6.7 & 408 \\
& Introvert & 4 & 56.2 & 60 & 53 & 8.9 & 2,9 & 225 \\
\hline
\end{tabular}

The table above shows that the scores of students with extrovert personality in the experimental class had an interval of 95-108, an average score of 99.7, and a variance of 32.9. Scores of students with introvert personality in the experimental class had 50-60 intervals, an average score of 55 , and a variance of 19.3. In the control class, students are also grouped into extroverts and introverts. Extrovert students have an interval of 95-110, an average score of 102 , and a variant of 46 . Meanwhile, introvert students have an interval of $53-60$, an average score of 56.2 , and a variance of 8.9 .

In getting the data of students' writing ability, a test is done which is a business letter writing test. Student writing ability data can be seen in the following table:

Table 3. Data on Students' Writing Ability in the Experimental Class and Control Class

\begin{tabular}{lcccccc}
\hline Class & N & Mean & SD & Variance & Max & Min \\
\hline Experimental & 16 & 82.5 & 7.6 & 57.3 & 96 & 72 \\
Control & 16 & 67.5 & 11.8 & 138.4 & 88 & 48 \\
\hline
\end{tabular}

To get the writing score, the score of the rubric of the score multiplied by 4 so that the highest score of students is 100. From the table above it is known that there are 16 students in the experimental class. The highest score is 96 and the lowest score is 72 . The average score of students is 82.5 with a variance of 57.3. In the control class, there are also 16 students. The highest score is 88 and the lowest score is 48 . The average score of students is 67.5 with a variance of 138.4 . This shows that there is a significant difference between students' writing ability in the experimental class and students in the control class. After 
getting data, the writing ability of students from both classes is grouped according to personality types. As in the following table:

Table 4. Students' Writing Ability Based on Personality in Experimental Class

\begin{tabular}{ccccc}
\hline \multirow{2}{*}{ No } & \multicolumn{2}{c}{ Students with Extrovert Personality } & \multicolumn{2}{c}{ Students with introvert Personality } \\
\cline { 2 - 5 } & \multicolumn{2}{c}{ Score } & \multicolumn{2}{c}{ Score } \\
\cline { 2 - 5 } & Personality & Writing Ability & Personality & Writing Ability \\
\hline 1 & 108 & 92 & 60 & 92 \\
2 & 99 & 76 & 57 & 76 \\
3 & 97 & 88 & 53 & 96 \\
4 & 95 & 72 & 50 & 76 \\
Total & 399 & 328 & 220 & 340 \\
Mean & 99.7 & 82 & 55 & 85 \\
Variance & 32.9 & 90.6 & 19.3 & 110,6 \\
\hline
\end{tabular}

The table shows the average score of students with extrovert personality in the experimental class is 99.7 with an average writing score of 82 . The average score of students with introvert personalities is 55 and their average writing score is 85 . While in the control group, the average score of students with an extrovert personality is 102 , and writing ability is 64 . The average score of students with introvert personality is 56.2 and the writing ability is 71 . Thus, students with introvert personality tend to have better writing scores than extrovert ones in both classes (experimental and control).

Table 5. Students' Writing Ability Based on Personality in Control

\begin{tabular}{ccccc}
\hline & \multicolumn{2}{c}{ Students with Extrovert Personality } & \multicolumn{2}{c}{ Students with introvert Personality } \\
\cline { 2 - 5 } No & \multicolumn{2}{c}{ Score } & \multicolumn{2}{c}{ Score } \\
\cline { 2 - 5 } & Personality & Writing Ability & Personality & Writing Ability \\
\hline 1 & 110 & 56 & 60 & 88 \\
2 & 105 & 64 & 57 & 48 \\
3 & 98 & 64 & 55 & 68 \\
4 & 95 & 72 & 53 & 80 \\
Total & 408 & 256 & 225 & 71 \\
Mean & 102 & 64 & 56.2 & 302 \\
Variance & 46 & 42.6 & 8.9 & \\
\hline
\end{tabular}

Hypothesis in this study are:

$\mathrm{H} 1$ : There is a significant impact of students' personalities on students' writing ability.

HO: There is no significant impact of students' personalities on students' writing ability.

The hypothesis analyzed by using a t-test. From the results obtained, the Pvalue interpretation is done with the test criteria is reject $\mathrm{H} 0$ or accept $\mathrm{H} 1$ if $\mathrm{P}$ - value $<\alpha$ and vice versa accept $\mathrm{H} 0$ or reject $\mathrm{H} 1$ if $\mathrm{P}$-value $>\alpha$, with $\alpha=0.05$. Based on calculations using SPSS, the $p$-score is $0.00<0.05$. So the $p$-score obtained is smaller than 0.05 so $\mathrm{HO}$ is rejected and $\mathrm{H} 1$ is accepted so there is a significant impact of students' personality $\mathrm{t}$ on students' writing ability. As shown in the following picture: 


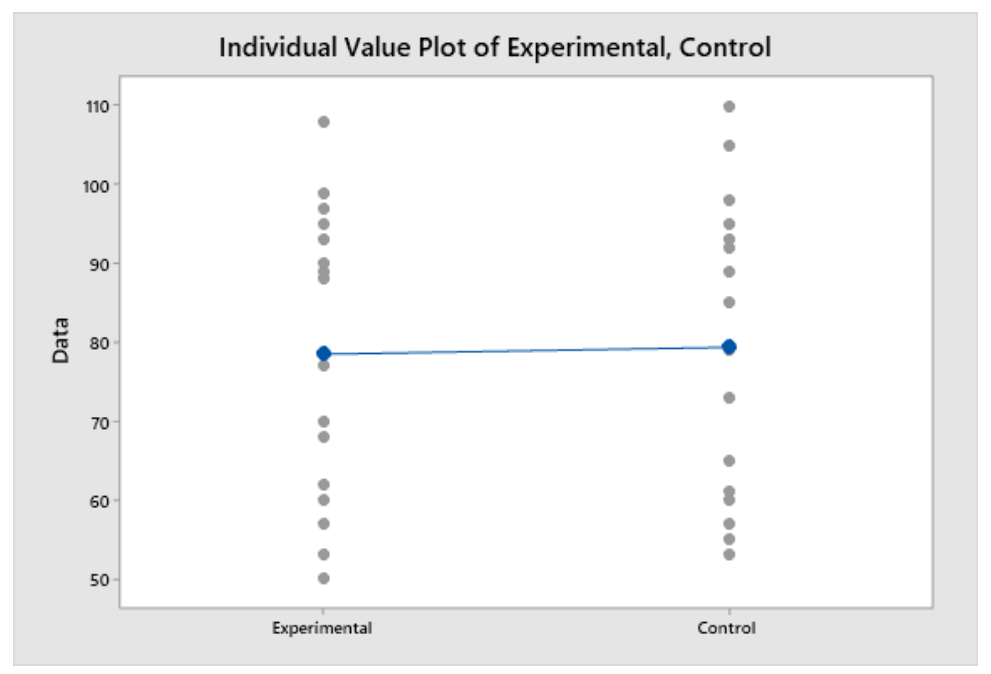

Figure 4. Hypothesis Testing

\subsection{Discussion}

Regarding the finding of the research, it can be known that in writing a business letters, students with introvert personalities have better writing scores than students with extrovert personalities in both classes (experimental and control). This result in line with (Ellis, 2008; Sanjaya \& Mokhtar, 2015) who found that introvert students perform better writing ability than extrovert students. $(H, 2001)$ also found evidently observed that some Indonesian EFL teachers and students have this assumption that introverts may perform better in conceptual tasks (i.e., writing) than extroverts when there is no requirement of oral performance and interactions. Moreover, (Ellis, 2008) found that introvert students are better at developing cognitive academic language proficiency (CALP) than extroverts because many introvert students spit up more time for reading, writing, and trying to produce accurate language. CALP is the students' ability to understand and express in both written and oral modes, concepts, and ideas that are relevant to success (Cummins, 2008). Thus, it can be known that introvert is better to construct the writing. And then, the present study is not the same as the previous research finding of (Wakamoto, 2000) who conveys that extroverts are better than introverts in language learning. and (Marefat, 2006; Nezhad \& Jahandar, S. Khodabandehlou, 2014) who mention that there is no significant difference between extroverts and introverts in language learning. The introvert and extrovert personalities show that they both have advantages and disadvantages in learning language skills. In writing skills, particularly in this study, it was found that apparently written products of students with introverted personalities showed better results.

Previous studies also found that introverts students have their strength in some aspects of language learning. In his study, (Boroujeni et al., 2015) find that introverts are usually in search of the best vocabulary choice; for this reason, they probably experience more difficulty in speaking an L2 fluently than extroverts. But the same reason has made their writing much more professional. Moreover, (Qanwal \& Ghani, 2019) exposed that introverts are better learners of ESL writing skills as compared to the extrovert especially in vocabulary, expression, and content. It is maybe because of the character of introvert students who think best themselves and processing ideas in their own mind well (Machnicka, 2010). A study from (Altunel, 2015) and (Carrell, P., Prince \& Astika, 1996) indicates that introverts would get higher scores than extroverts in Use of English (Grammatical forms, form, and meaning, etc.) after receiving input-based instruction. The use of English section is designed to measure how much learners know about grammatical forms and their meanings, and assesses students' knowledge of grammatical forms, knowledge of explicit and implicit (vocabulary) meaning, and both grammatical forms and meaning together. It has been reported that introverts generally listen to language by focusing on each individual meaning of a new word, and they distinguish grammatical differences in language (Kezwer, 1987). 
(Boroujeni et al., 2015) also gained if introverts significantly outperformed extroverts in all subsets of writing components except organization. This may be due to some of the introverts' personal characteristics that the extroverts lack, such as being careful, having more concentration in their solitude, and ability to generate many more ideas. It also the teachers because of teacher can group students based on their personality traits and give them appropriate communicative tasks to develop their writing skills (Ahmadian \& Yadegari, 2011). However, present study finds introvert has a better score in all aspects of writing such as content, mechanics, vocabulary, organization, and grammar based on students' writing result on a business letter. Despite, the difference of scores in each aspect are not really huge but mostly introvert get a better score than extrovert ones.

\section{Conclusion and Suggestion}

Students have different personalities in language learning, some students tend to be extrovert and the others and introvert. It can have an impact on students' ability in mastering English. This study focus on writing ability. Based on the result of the finding, it can be known that there is a significant impact of personality types on students' writing ability. Students with Introvert personality have better writing scores in all writing aspects than students with extrovert personalities in both classes (experimental and control). Therefore, personality can be one of consideration for the teacher in solving the studens learning problem, because the teacher is not also demanded to know students' abilities from external factors but also the internal factors such as personality.

This study was funded by The Ministry of Research, Technology, and Higher Education (Kemenristekdikti) of Indonesia. For that, researchers would like to say thank to Directorate of Research and Society Dedication (DRPM) in the Novice Lecturer Research (PDP) scheme and LPPM STKIP Muhammadiyah Sungai Penuh who managed research grants for us. We also thank all parties who supported and participated in the accomplishment of the research and article.

\section{References}

Ahmadian, M., \& Yadegari, H. (2011). The relationship between extraversion/introversion and the use of strategic competence in oral referential communication. Journal of English Language Teaching and Learning, 22(7), 1-26.

Ahour, T., \& Haradasht, P. N. (2014). The Comparative Effect of Using Competitive and Cooperative Learning on the Reading Comprehension of Introvert and Extrovert EFL Learners. Journal Advances in Language and Literary Studies, 5(4), 33-39.

Altunel, V. (2015). The Impact of Extroversion and Introversion on Language Learning In An Input-Based EFL Setting. University Of Kansas.

Arikunto, S. (2008). Dasar-Dasar Evaluasi Pendidikan (Edisi Revisi). Jakarta: Bumi Aksara.

Bilal, H, A., Tariq, A. R., Din., Latif, H., \& Anjum, M. N. (2013). Investigating the Problems Faced by the Teachers in Developing English Writing Skills. Asian Journal of Social Science and Humanities, 2(3), 238-244.

Boroujeni, A. A. J., Roohani, A., \& Hasanimanesh, A. (2015). The Impact of Extroversion and Introversion Personality Types on EFL Learners' Writing Ability. Theory and Practice in Language Studies, 5(1), 212. https://doi.org/10.17507/tpls.0501.29

Brown, H. D. (2000). Principles of Language Learning and Teaching (Fourth). New York: Addison Wesley Longman, Inc.

Carrell, P., Prince, M., \& Astika, G. (1996). Personality Types and Language Learning in an EFL Context. Language Learning, 46(1), 75-99.

Cummins, J. (2008). BICS and CALP: Empirical and theoretical status of the distinction. Encyclopedia of Language and Education, 2(2), 71-83.

Dewaele, J. M. (2005). Investigating the psychological and emotional dimensions in instructed language learning: Obstacles and possibilities. Modern Language Journal, 89(3), 367-380. https://doi.org/10.1111/j.1540-4781.2005.00311.x 
Dhanya, M., \& Alamelu, C. (2019). Factors influencing the acquisition of writing skills. International Journal of Innovative Technology and Exploring Engineering, 8(7C2), 259-263.

Ellis, R. (2008). The Study of Second Language Acquisition. Oxford: Oxford University Press.

Faisal, R. A. (2019). Influence of Personality and Learning Styles in English Language Achievement. Open Journal of Social Sciences, 07(08), 304-324. https://doi.org/10.4236/jss.2019.78022

Fareed, M., Ashraf, A., \& Bilal, M. (2016). ESL Learners' Writing Skills: Problems, Factors and Suggestions. Journal of Education \& Social Sciences, 4(2), 83-94. https://doi.org/10.20547/jess0421604201

Fatimawati, I. (2015). Irrelated Influence of Internal and External Factors on Malaysian Learners' Self-concept in Academic Writing. The Journal of Asia TEFL, 12(1), 79-115.

H, K. (2001). Extraversion-Introversion and grammatical knowledge. Tehran.

Kezwer, P. (1987). The extrovert vs. the introvert personality and second language learning. TESL Canada Journal, 5(1), 45-58.

Laney, M. O., \& Laney, M. L. (1987). The introvert and Extrovert in Love: Making it Work When Opposites Attract. Ontario: New Harbinger Publications, Inc.

Loewen, S., \& Reinders, H. (2007). Key Concepts in Second Language. New York: Palgrave Macmillan.

Machnicka, J. (2010). The Role of Personality Variables of Introversion and Extroversion and Language Aptitude in the Proficiency of EFL. EFL Journal, 6(3).

Mansouri Nejad, A., Bijami, M., \& Ahmadi, M. R. (2012). Do Personality Traits Predict Academic Writing Ability? An EFL Case Study. English Linguistics Research, 1(2), 145-152. https://doi.org/10.5430/elr.v1n2p145

Marefat, F. (2006). Student writing, personality type of the student and the rater: Any interrelationship? Reading Matrix: An International Online Journal, 6(2), 116-124.

Marwa, W. S., \& Thamrin, N. R. (2016). Extrovert Personality and Its Impact on Students' Argumentative Essay Writing Skill. English Review: Journal of English Education, 4(2), 267. https://doi.org/10.25134/erjee.v4i2.340

Mastuti, E. (2005). Analisis Faktor Alat Ukur Kepribadian Big Five (Adaptasi dari IPIP) pada Mahasiswa Suku Jawa. Jurnal INSAN, 7(3).

Nezhad, S. H., \& Jahandar, S. Khodabandehlou, M. (2014). The Impact of Extroversion Vs. Introversion on Iranian EFL Learners' Writing Ability. Indian Journal of Fundamental and Applied Life Sciences, 4(1), 119-128.

Nicholson, N. (2015). How to Make Friends as an Introvert: Discover Introvert-Friendly Ways to Meet New People, Improve Your Social Skills, and Make New Friends. New York: Blue Sky Publishing.

Pritchard, A. (2014). Ways of Learning: Learning Theories and Learning Styles in the Classroom (Third). New York: Routledge.

Qanwal, S., \& Ghani, M. (2019). Relationship Between Introversion/Extroversion Personality Trait and Proficiency in ESL Writing Skills. International Journal of English Linguistics, 9(4), 107. https://doi.org/10.5539/ijel.v9n4p107

Sanjaya, D., \& Mokhtar, A. A. S. (2015). Relationship between Introversion/Extroversion Personality Trait and Proficiency in ESL Writing Skill. Asian EFL Journal Professional Teaching Articles, (87), 4-16.

Shahila, Zafar, \& Meenakshi, K. (2012). A Study on the Relationship Between ExtroversionIntroversion and Risk-Taking in the Context of Second Language Acquisition. International Journal of Research Studies in Language Learning, 1(1), 33-44.

Shrum, J., Glisan, L. and, \& W, E. (2010). Teacher's Handbook Contextualized Language Instruction (5th Ed) (Fifth). Boston: Cengage Learning.

Suliman, F. H. A. (2014). The Role of Extrovert and Introvert Personality in Second Language Acquisition. Proceedings of SOCIOINT14- International Conference on Social Sciences and Humanities.

Suryasubrata, S. (1995). Psikologi Kepribadian. Jakarta: PT Raja Grafindo Persada. 
Wakamoto, N. (2000). Extroversion/Introversion in Foreign Language Learning:Interactions With Learner Strategy Use. IRAL. International Review of Applied Linguistics in Language Teaching, 38(1), 71-81.

Zabihi, R. (2011). Personality in English Proficiency and Achievement Continental. Education Research, 4(1), 1-6.

Zainuddin, Z. (2016). The Impact of Personality: Extrovert vs. Introvert on the Ability in Syntax in Essay Writing. Studies in English Language and Education, 3(2), 162. https://doi.org/10.24815/siele.v3i2.4963 